\title{
MENINGKATKAN MOTIVASI DAN HASIL BELAJAR SISWA KONSEP HIDROKARBON DENGAN MENGGUNAKAN MODEL PEMBELAJARAN COOPERATIVE SCRIPT BERBANTUAN MEDIA ADOBE FLASH PADA SISWA KELAS XI MIA-3 MAN 3 BANJARMASIN TAHUN PELAJARAN 2016/2017
}

\author{
Chairunnisa \\ Madrasah Aliyah Negeri 3 Banjarmasin \\ Email: nisa63ch@gmail.com
}

\begin{abstract}
Has been done a research on the implementation of Cooperative Script model aided by Adobe Flash media on hydrocarbon material in class XI MIA-3 MAN 3 Banjarmasin in 2016/2017 academic years. This research aims to know the increase in motivation, improved cognitive and affective learning outcomes, student activities, and students' response to learning using Cooperative Script model aided by Adobe Flash media. This research uses classroom action research design, with 2 cycles. Each cycle consists of planning, action, observation and evaluation as well as analysis and reflection. The subject were students of class XI MIA -3 MAN 3 Banjarmasin amounting to 39 students Data collection techniques use test techniques, observations, and questionnaires. The results showed that: (1) an increase in motivation of students in the first cycle $68,68 \%$ to $76,89 \%$ in the second cycle, (2) An increase completeness cognitive learning outcomes of students from $82.05 \%$ to $87.09 \%$, (3) An increase in affective learning outcomes of students from $69.54 \%$ to $79.33 \%$, (4) the activity of students in a very active criteria, (5) Cooperative Script model aided by Adobe Flash media received a positive response from students.
\end{abstract}

Keywords: cooperative script, motivation, cognitive learning outcomes

\begin{abstract}
ABSTRAK
Telah dilakukan penelitian mengenai implementasi model Cooperative Script yang dibantu media Adobe Flash pada bahan hidrokarbon di kelas XI MIA-3 MAN 3 Banjarmasin pada tahun akademik 2016/2017. Penelitian ini bertujuan untuk mengetahui peningkatan motivasi, peningkatan hasil belajar kognitif dan afektif, aktivitas siswa, dan respon siswa terhadap pembelajaran dengan menggunakan model Cooperative Script yang dibantu oleh media Adobe Flash. Penelitian ini menggunakan desain penelitian tindakan kelas, dengan 2 siklus. Setiap siklus terdiri dari perencanaan, tindakan, observasi dan evaluasi dan analisis serta refleksi. Subjek penelitian adalah siswa kelas XI MIA -3 MAN 3 Banjarmasin berjumlah 39 siswa. Teknik pengumpulan data menggunakan teknik pengujian, observasi, dan kuesioner. Hasil penelitian menunjukkan bahwa: (1) peningkatan motivasi siswa pada siklus I 68,68\% menjadi 76,89\% pada siklus II, (2) peningkatan kelengkapan hasil belajar kognitif siswa dari 82,05\% menjadi 87,09\%, (3) Peningkatan hasil pembelajaran afektif siswa dari 69,54\% menjadi 79,33\%, (4) aktivitas siswa dalam kriteria yang sangat aktif, (5) Model naskah koperasi dibantu media Adobe Flash mendapat respon positif dari siswa.
\end{abstract}

Kata kunci: cooperative script, motivasi, hasil belajar kognitif 


\section{PENDAHULUAN}

Ilmu kimia merupakan ilmu yang mempelajari struktur materi, sifat-sifat materi, perubahan suatu materi menjadi materi lain, serta energi yang menyertai perubahan materi. Berdasarkan hasil ulangan bidang studi kimia di MAN 3 Banjarmasin diperoleh informasi bahwa materi kimia khususnya hidrokarbon merupakan salah satu materi yang sulit bagi siswa. Hal ini dapat dilihat dari nilai siswa untuk materi hidrokarbon yang masih dibawah kriteria ketuntasan minimum (KKM) yang ditetapkan sekolah yaitu sebesar 75 .

Data hasil ulangan siswa kelas XI MAN 3 Banjarmasin tahun pelajaran 2015/2016 pada materi hidrokarbon, hanya $51 \%$ siswa yang telah mencapai kriteria ketuntasan minimum yang ditetapkan sekolah. Hal ini menunjukkan bahwa siswa mengalami kesulitan belajar dan berdampak pada hasil belajar pada materi hidrokarbon yang masih tergolong rendah. Kesulitan yang dialami siswa pada materi hidrokarbon ini yaitu dalam penamaan senyawa hidrokarbon dan keisomeran.

$$
\text { Salah satu faktor yang }
$$

menyebabkan kesulitan siswa dalam memahami materi hidrokarbon adalah minat dan motivasi belajar siswa saat proses pembelajaran yang rendah. Rendahnya minat dan motivasi belajar siswa disebabkan karena selama proses pembelajaran guru lebih sering menggunakan metode konvensional, dimana pembelajaran berpusat pada guru sehingga menyebabkan siswa menjadi pasif, cenderung menunggu penjelasan dan siswa jarang diminta mengungkapkan alasan terhadap hasil jawaban dari pemikirannya sehingga siswa sulit mengkomunikasikan ide dan pemikirannya dengan baik.

$$
\text { Permasalahan di atas }
$$
menunjukkan bahwa pembelajaran kimia pada materi hidrokarbon perlu diperbaiki, untuk memperbaiki proses pembelajaran diperlukan sebuah model yang dapat membuat siswa lebih tertarik dan aktif saat proses pembelajaran. Model pembelajaran kooperatif adalah salah satu model yang melibatkan keaktifan siswa. Pembelajaran kooperatif merupakan bentuk pembelajaran dengan cara siswa belajar dan bekerja dalam kelompok kecil secara kolaboratif (Majid, 2013).

Cooperative Script salah satu model pembelajaran kooperatif yang dapat membuat siswa menjadi lebih aktif saat proses belajar mengajar berlangsung. Model pembelajaran Cooperative Script adalah model pembelajaran yang mengarahkan siswa untuk bekerja berpasangan dan secara lisan mengikhtisarkan bagian-bagian dari materi yang dipelajari. Cooperative Script memungkinkan siswa untuk menemukan ide-ide pokok dari gagasan besar yang disampaikan oleh guru (Huda, 2013).

Materi hidrokarbon menuntut siswa untuk banyak membaca dan latihan agar dengan sendirinya siswa mampu mengingat dan lebih mudah memahami konsep tentang hidrokarbon, sehingga sangat cocok dengan model pembelajaran Cooperative Script. Model pembelajaran ini dapat membantu siswa melatih pendengaran, ketelitian dan kecermatan; melatih siswa belajar dalam peran; dan melatih siswa mengungkapkan kesalahan orang lain.

Salah satu media pembelajaran yang dapat digunakan saat penerapan model Cooperative Script adalah Adobe Flash. Media Adobe Flash merupakan program aplikasi yang memungkinkan untuk pembuatan animasi. Animasi adalah suatu karya yang memiliki banyak elemen antara lain teks, gambar, suara, dan gerak. Adobe Flash sering digunakan untuk membuat media presentasi maupun media pembelajaran. Hal ini karena lebih menarik dan dapat didesain sesuai dengan kebutuhan (Rahmadi, 2013).

Berdasarkan uraian di atas, peneliti tertarik untuk melakukan penelitian tindakan kelas dengan menerapkan model Cooperative Script berbantuan media Adobe Flash untuk meningkatkan motivasi 
dan hasil belajar siswa konsep hidrokarbon pada kelas XI MIA - 3 MAN 3 Banjarmasin pada tahun pelajaran 2016/2017.

\section{METODE PENELITIAN}

Penelitian ini dilaksanakan dengan menggunakan rancangan penelitian tindakan kelas (classroom action research) yang merupakan penelitian tindakan yang dilakukan di kelas dengan tujuan memperbaiki/meningkatkan mutu praktik pembelajaran. Penelitian tindakan kelas terdiri dari empat kegiatan utama pada setiap siklus masing-masing terdiri dari tahapan-tahapan: (1) perencanaan, (2) pelaksanaan tindakan, (3) observasi dan evaluasi serta, (4) analisis dan refleksi.

Penelitian yang dilaksanakan dalam dua siklus pembelajaran ini diharapkan motivasi dan hasil belajar siswa dalam materi hidrokarbon dapat ditingkatkan. Siklus I dan II dilaksanakan dalam dua kali pertemuan dengan 2 kali tes kognitif di setiap akhir siklus (evaluasi). Pada siklus I membahas tentang keunikan atom karbon dan senyawa hidrokarbon. Selanjutnya, setelah dilakukan refleksi terhadap pelaksanaan kegiatan pembelajaran pada siklus I dilanjutkan pelaksanaan siklus II. Pada pertemuan pertama dan kedua siklus II membahas keisomeran dan sifat-sifat hidrokarbon.

Penelitian dilaksanakan pada bulan Juli sampai dengan bulan September 2016 bertempat di MAN 3 Banjarmasin. Subjek penelitian adalah siswa kelas XI MIA-3 tahun pelajaran 2016/2017 dengan jumlah siswa 39 orang yang terdiri dari 10 siswa laki-laki dan 29 siswa perempuan. Tingkat kemampuan dan daya serap siswa pada kelas tersebut bervariasi.

Instrumen penelitian antara lain berupa tes dan non tes. Instrumen tes yang digunakan berbentuk soal objektif untuk mengukur hasil belajar kognitif siswa yang berjumlah 20 soal dengan 5 pilihan jawaban yang terdiri dari 1 pilihan benar dan 4 jawaban pengecoh. Teknik penskoran untuk instrumen tes objektif ditentukan dengan cara memberi skor 1 untuk jawaban yang benar dan skor 0 untuk jawaban yang salah.

Instrumen non tes yang digunakan dalam penelitian ini adalah observasi aktivitas guru dan siswa, observasi afektif siswa, angket motivasi siswa serta angket respon siswa. Angket motivasi siswa yang digunakan mengadaptasi dan memodifikasi dari angket model ARCS (Attention, Relevance, Confidence, and Satisfaction) dari Keller. Angket motivasi siswa terdiri atas 27 pernyataan menggunakan skala Likert dengan rentang 1-5 untuk pernyataan yaitu 1 = sangat tidak setuju, $2=$ tidak setuju, $3=$ ragu-ragu, $4=$ setuju, dan $5=$ sangat setuju.

Analisis motivasi siswa dilakukan untuk mengetahui seberapa besar peningkatan motivasi belajar setiap siswa pada materi hidrokarbon setelah diterapkan pembelajaran Cooperative Script berbantuan media Adobe Flash. Motivasi siswa diskor dengan cara menghitung jumlah total skor dibagi dengan jumlah pernyataan.

$$
\text { Skor rata-rata }=\frac{\Sigma \text { total } \text { skor }}{\Sigma \text { pernyataan }}
$$

Klasifikasi rata-rata skor angket dapat diterjemahkan sebagai berikut

Tabel 1. Kategori skor motivasi siswa

\begin{tabular}{cc}
\hline Skor rata-rata & Kategori \\
\hline $1,00-1,49$ & Sangat kurang \\
\hline $1,50-2,49$ & Kurang baik \\
\hline $2,50-3,49$ & Cukup baik \\
\hline $3,50-4,49$ & Baik \\
\hline $4,50-5,00$ & Sangat baik \\
\hline
\end{tabular}

Keberhasilan siswa dalam memahami konsep hidrokarbon dilihat dari banyaknya siswa yang menjawab benar pada butir soal yang diujikan. Rumus penskoran yang digunakan adalah:

Keterangan:

$$
\text { Skor }=\frac{\mathrm{Jb}}{\mathrm{N}} \times 100
$$

$\mathrm{Jb}=\begin{aligned} & \text { Banyaknya butir soal yang dijawab } \\ & \text { benar }\end{aligned}$

$\mathrm{N}$ = Banyaknya butir soal (Ratumanan \& Laurens, 2003) 
Kemudian, mengukur ketuntasan belajar secara klasikal digunakan rumus:

$$
\mathrm{P}=\frac{f}{N} \times 100 \%
$$

Untuk mendeskripsikan banyaknya siswa yang mengalami keberhasilan dalam mempelajari konsep hidrokarbon diklasifikasikan berdasarkan tingkat kemampuan pada Tabel 2.

Tabel 2. Tingkatan Hasil Belajar

\begin{tabular}{cc}
\hline Hasil Belajar (\%) & Tingkat \\
\hline 100 & Istimewa/ maksimal \\
\hline $76-99$ & Baik sekali/ optimal \\
\hline $60-75$ & Baik/ minimal \\
\hline$<60$ & Kurang \\
\hline
\end{tabular}

\section{HASIL DAN PEMBAHASAN}

\section{Hasil Penelitian}

Hasil pelaksanaan dan pengamatan penelitian pada siklus I dan siklus II berupa aktivitas guru, aktivitas siswa, afektif siswa, motivasi belajar siswa dan hasil belajar kognitif siswa menggunakan model Cooperative Script berbantuan media Adobe Flash. Peningkatan aktivitas guru setiap pertemuan dapat dilihat pada Gambar 1.

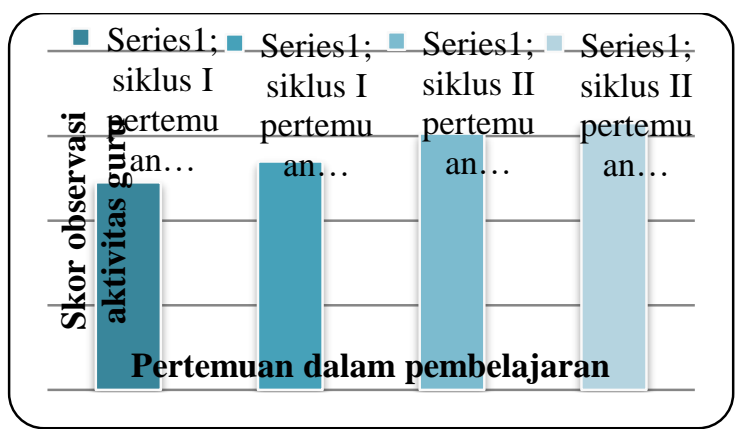

Gambar 1. Diagram Hasil Observasi Aktivitas Guru

Diagram rata-rata aktivitas guru pada siklus I dan II dapat dilihat pada Gambar 2 di bawah ini.

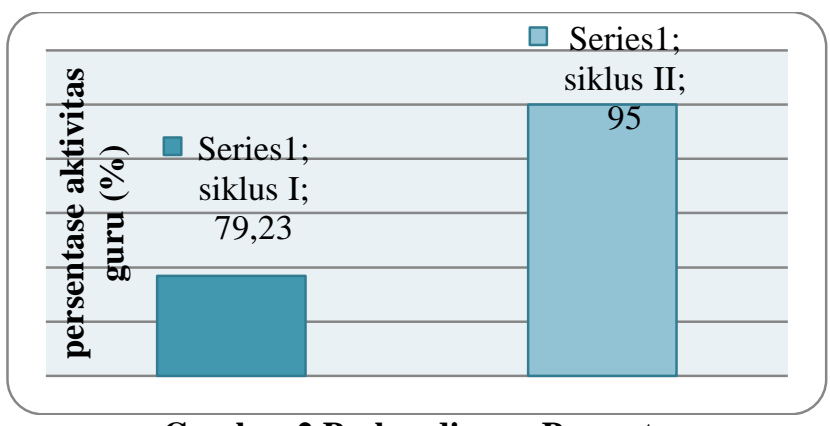

Gambar 2 Perbandingan Persentase Aktivitas Guru pada Siklus I dan II

Peningkatan aktivitas siswa setiap pertemuan dapat dilihat pada Gambar 3 berikut.

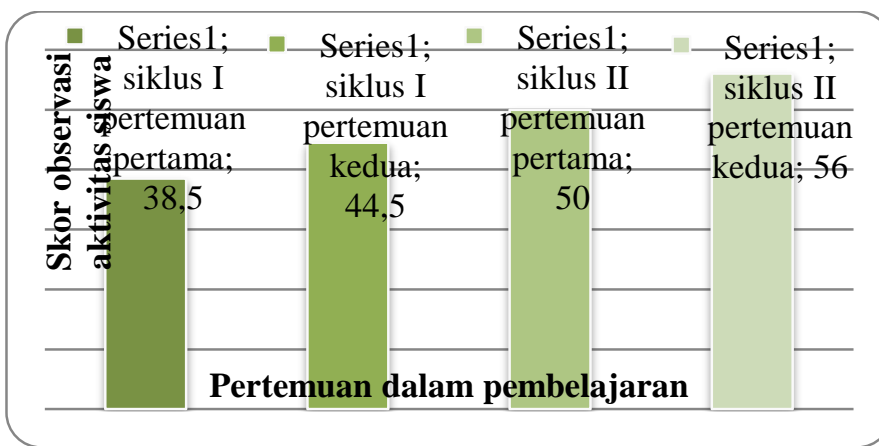
Gambar 3. Diagram Hasil Observasi Aktivitas
Siswa

Diagram rata-rata aktivitas siswa pada siklus I dan II dapat dilihat pada Gambar 4 di bawah ini.

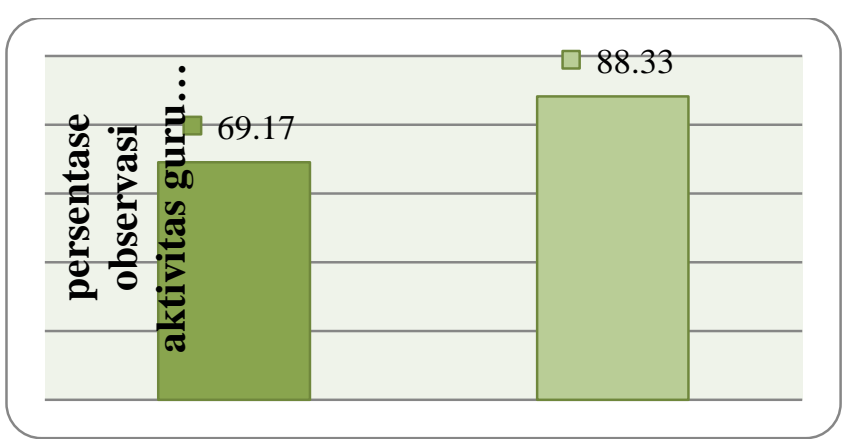

Gambar 4. Perbandingan Persentase Aktivitas Siswa pada Siklus I dan II

Peningkatan afektif siswa setiap pertemuan dapat dilihat pada Gambar 5 berikut. 


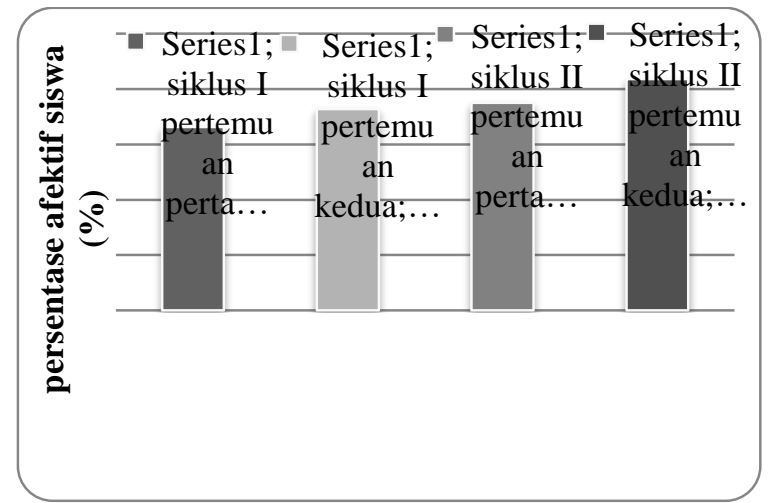

Gambar 5. Diagram Hasil Observasi Afektif Siswa

Diagram rata-rata afektif siswa pada siklus I dan II dapat dilihat pada Gambar 6 di bawah ini.

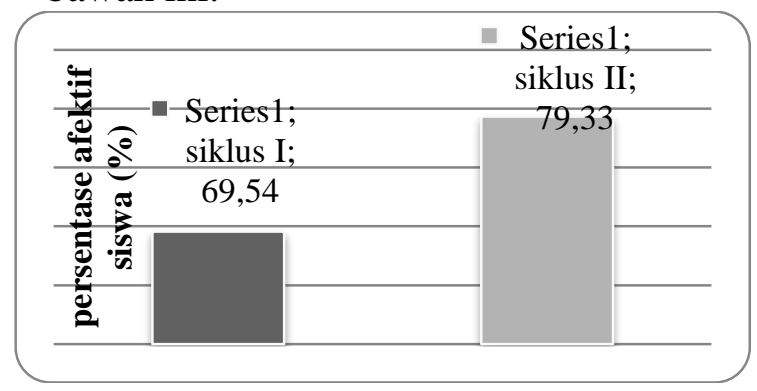

Gambar 6. Perbandingan Persentase Afektif Siswa pada Siklus I dan II

Angket motivasi diberikan pada setiap siswa ketika akhir siklus I dan II. Peningkatan motivasi siswa terhadap pembelajaran hidrokarbon menggunakan model pembelajaran Cooperative Script berbantuan media Adobe Flash setiap pertemuan untuk setiap indikator dapat dilihat pada Gambar 7 berikut.

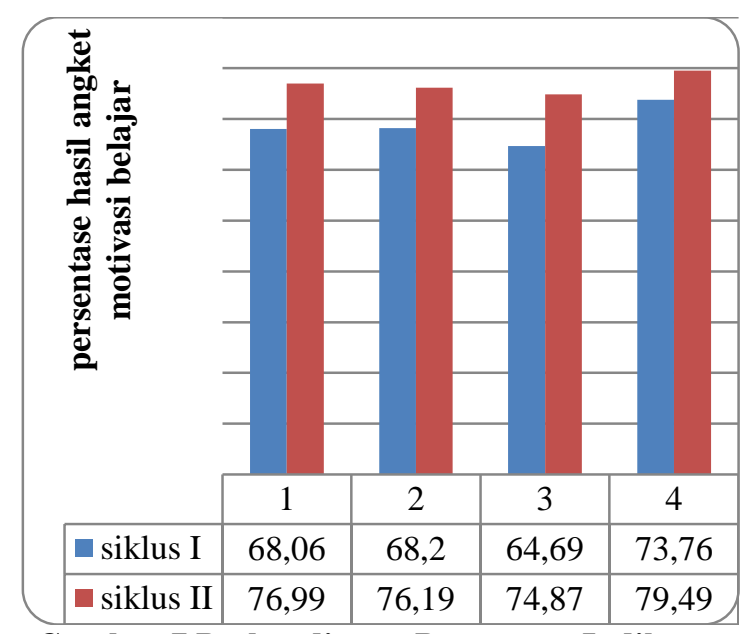

Gambar 7 Perbandingan Persentase Indikator Motivasi Siswa
Data respon siswa terhadap pembelajaran pada materi hidrokarbon dengan menggunakan model pembelajaran Cooperative Script berbantuan media Adobe Flash dapat dilihat pada Gambar 8.

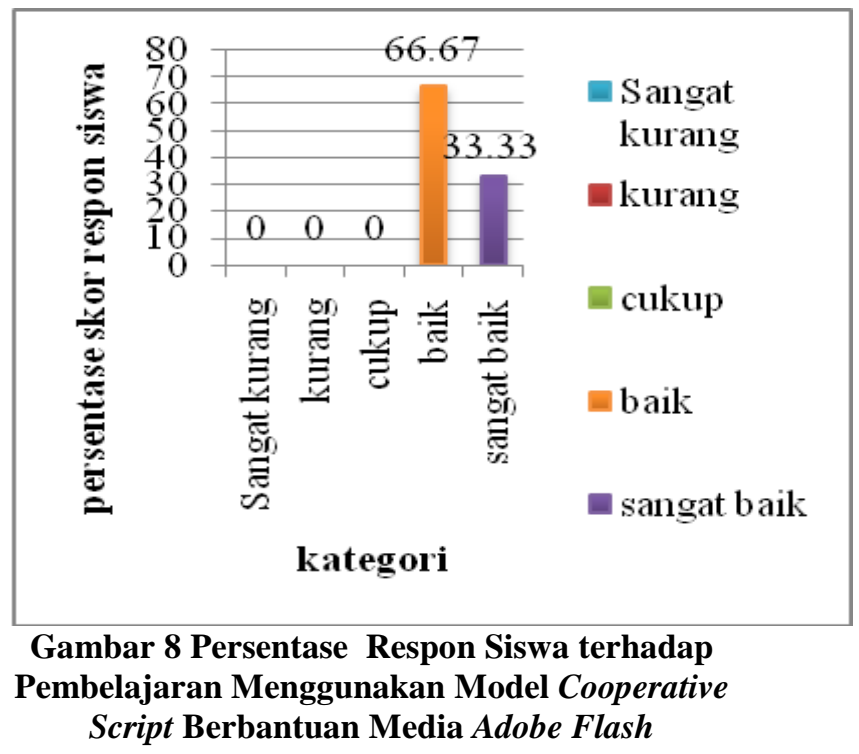

\section{Pembahasan}

\section{Aktivitas Guru}

Proses pembelajaran pada siklus I dengan menggunakan model pembelajaran Cooperative Script berbantuan media Adobe Flash secara keseluruhan telah dilaksanakan dengan baik namun masih ada beberapa tahapan yang kurang optimal. Hal ini berarti secara umum guru sudah dapat menyesuaikan diri dalam proses pembelajaran menggunakan model pembelajaran Cooperative Script berbantuan media Adobe Flash sesuai pada rencana proses pembelajaran (RPP).

Setelah siklus I berakhir, penilaian aktivitas guru dilanjutkan pada siklus II. Dimana dari siklus I dijadikan refleksi untuk memperbaiki aktivitas guru yang masih kurang agar sesuai dengan apa yang ingin dicapai. Pada siklus II ini guru melakukan perbaikan dalam proses pembelajaran, yaitu dengan berusaha mengefisienkan waktu pembelajaran dan pengelolaan kelas yang baik.

Suasana pembelajaran pada siklus II lebih terkendali jika dibandingkan suasana pembelajaran pada siklus I. Hal ini sejalan dengan hasil penelitian yang dilakukan oleh 
Andreastomo (2013) yaitu model pembelajaran Cooperative Script dapat meningkatkan aktivitas guru. Dengan demikian pada siklus II aktivitas guru sudah tergolong sangat baik, guru lebih meningkatkan motivasi siswa untuk lebih aktif dalam diskusi dan berani dalam mengemukakan pendapat saat presentasi.

\section{Aktivitas Siswa}

Aktivitas siswa pada pertemuan pertama berdasarkan hasil observasi diketahui bahwa kegiatan pembelajaran berlangsung cukup aktif dengan persentase $64,17 \%$ sedangkan pada pertemuan kedua kegiatan pembelajaran berlangsung aktif dengan persentase $74,17 \%$. Pada siklus I pertemuan pertama hingga pertemuan kedua aktivitas siswa mengalami peningkatan sebesar $10 \%$. Secara keseluruhan aktivitas siswa pada siklus I tergolong dalam kategori aktif, namun siswa masih belum terbiasa menerapkan model pembelajaran Cooperative Script dan menggunakan media Adobe Flash dalam pembelajaran.

Peningkatan persentase aktivitas siswa yang terlihat dari siklus I ke siklus II ini dikarenakan siswa sudah termotivasi dan memiliki rasa tanggung jawab dalam mengikuti pembelajaran dengan menggunakan model pembelajaran Cooperative Script Adobe Flash. Hal ini sejalan dengan penelitian Tiara (2014) yang mengatakan bahwa siswa menjadi lebih aktif saat mengikuti pembelajaran menggunakan model Cooperative Script. Dengan demikian penelitian tindakan kelas ini berhasil dan hipotesis diterima yang menyatakan proses pelaksanaan pembelajaran dengan menggunakan model pembelajaran Cooperative Script berbantuan media Adobe Flash dapat meningkatkan aktivitas siswa yang menjadikan siswa lebih aktif dalam proses pembelajaran.

\section{Afektif siswa}

Afektif siswa secara keseluruhan pada siklus I dan siklus II terjadi peningkatan, dimana afektif siswa pada siklus I dengan kategori baik sebesar $69,54 \%$, sedangkan pada siklus II dengan kategori baik sebesar 79,33\%. Berdasarkan hasil perhitungan penilaian observer pada siklus II menyatakan bahwa afektif siswa pada proses belajar mengajar menggunakan model pembelajaran Cooperative Script berbantuan media Adobe Flash pada siklus ini mengalami peningkatan yaitu sebesar 9,79\%. Hal ini karena adanya perbaikan dalam mengajar guru dan aktivitas siswa sehingga aspek afektif siswa yang berupa sikap akan mengalami perubahan yang lebih baik dalam mengikuti pembelajaran. Hal ini sejalan dengan penelitian Soelistiyanto (2014) yang menyatakan bahwa terjadi peningkatan hasil belajar terutama dalam ranah kognitif dan afektif setelah penerapan model pembelajaran Cooperative Script.

\section{Motivasi siswa}

\section{(1) Perhatian (Attention)}

Pada siklus I siswa sudah mempunyai motivasi yang cukup baik dalam hal perhatian. Setelah dilakukan refleksi pada siklus I, pada siklus II guru melakukan perbaikan. Guru memotivasi siswa untuk lebih memperhatikan pelajaran dengan baik dengan cara menggunakan teknik bertanya agar bagi siswa yang kurang memperhatikan pelajaran dapat kembali fokus pada pelajaran. Hal ini sesuai dengan pembahasan tentang teori motivasi Keller yang diulas oleh Abidin (2006) yang mengemukakan bahwa salah satu cara untuk merangsang perhatian siswa adalah dengan cara menggunakan teknik bertanya agar siswa terlibat langsung dalam pembelajaran.

\section{(2) Relevansi (Relevance)}

Pada siklus I siswa sudah mempunyai motivasi yang cukup baik dalam hal relevansi. Setelah dilakukan refleksi pada siklus I, pada siklus II guru melakukan perbaikan. Guru memotivasi siswa agar dapat mengaitkan pengetahuan yang telah mereka miliki dengan 
pengetahuan yang akan dipelajari. Salah satu cara yang dilakukan agar motivasi siswa pada indikator ini meningkat adalah dengan menekankan manfaat atau tujuan dari pembelajaran. Hal ini sesuai dengan pembahasan tentang teori motivasi Keller yang diulas oleh Abidin (2006) yang mengemukakan bahwa cara untuk menunjukkan relevansi pembelajaran diantaranya menyampaikan manfaat pembelajaran dan memberikan latihan soal yang berhubungan dengan kondisi siswa.

\section{(3) Percaya Diri (Confidence)}

Pada proses pembelajaran siklus I hanya sebagian siswa yang memiliki percaya diri baik, hal ini terlihat dari tahap diskusi yang dilakukan siswa. Saat berdiskusi, masih banyak siswa yang kurang berani mengemukakan pendapat dan mempresentasikan hasil diskusi. Setelah dilakukan refleksi pada siklus I, pada siklus II guru melakukan perbaikan. Guru memotivasi siswa agar memiliki percaya diri yang baik dengan cara meyakinkan siswa bahwa mereka telah memahami materi dan bisa mengemukakan pendapat serta mempresentasikan hasil diskusi. Selain itu, guru juga menegaskan bahwa tidak ada sanksi jika hasil diskusi mereka tidak sesuai dengan materi atau salah agar siswa menjadi lebih berani dan percaya diri. Hal ini sesuai dengan pendapat Frejnan dalam Abidin (2006) yang mengemukakan bahwa cara untuk menanamkan rasa percaya diri dalam pembelajaran salah satunya adalah memberikan memberikan umpan balik dengan menyebutkan pemahaman yang dimiliki siswa dan kelemahan siswa yang harus dikembangkan.

\section{(4) Kepuasan (Satisfaction)}

Saat proses pembelajaran siswa telah memiliki kepuasan yang baik karena selama proses pembelajaran guru selalu berusaha membuat siswa merasa puas dengan cara memberikan pujian secara verbal maupun nonverbal atas kinerja siswa. Pada siklus II guru tidak hanya memberikan pujian tetapi juga memberikan hadiah pada kelompok yang aktif selama proses pembelajaran. Hal ini sejalan dengan pendapat Dimyati \& Mudjiono (2009) yang mengemukakan bahwa hadiah dan hukuman dapat digunakan untuk meningkatkan kegiatan siswa dan berkaitan dengan motivasi ekstrinsik siswa.

\section{Hasil Belajar Kognitif}

Pada siklus I, persentase ketuntasan hasil belajar siswa sebesar $71,79 \%$ sedangkan pada siklus II persentase ketuntasan hasil belajar siswa meningkat menjadi $82,05 \%$ menurut kriteria keberhasilan dari Djamarah dan Zain (2010) termasuk dalam kriteria baik sekali. Pada hasil belajar siklus I skor tertinggi yang dicapai siswa adalah 100 dan skor terendah adalah 50 dan terdapat 11 siswa yang belum tuntas atau belum mencapai KKM. Pada pembelajaran siklus II, indikator yang belum tuntas pada siklus I dibahas kembali disamping juga melanjutkan indikator pembelajaran selanjutnya. Pada hasil tes siklus II, terdapat 32 siswa yang mendapat kategori tuntas sedangkan 7 siswa berada dalam kategori tidak tuntas. Hal ini sejalan dengan hasil penelitian yang dilakukan oleh Soelistiyanto (2014) yaitu hasil belajar siswa meningkat saat diterapkan model pembelajaran Cooperative Script.

Meningkatnya hasil belajar siswa dalam pembelajaran menggunakan model pembelajaran Cooperative Script berbantuan media Adobe Flash ini dapat terjadi karena pada proses pembelajaran dilakukan beberapa tindakan, antara lain :

(1) Memberikan tugas untuk membaca dan meringkas script yang berisikan ide pokok/tujuan, materi dan contoh soal untuk membangun pemahaman siswa agar siswa mengingat materi lebih lama dan menemukan ide pokok materi sebelum mendapat penjelasan dari guru.

(2) Melakukan diskusi kelompok yang membahas ringkasan materi agar 
siswa mampu mentransfer materi dan mengkomunikasikan hasil bacaannya.

(3)

Melalui diskusi siswa memperhatikan penjelasan dari teman sekelompoknya dan mengoreksi apabila dalam penjelasan tersebut terdapat kesalahan.

(4) Guru memberikan penguatan untuk membenarkan konsep yang telah diketahui siswa secara mandiri dan menekankan hal-hal yang penting dalam materi.

(5) Membuat kesimpulan untuk meningkatkan ingatan siswa terhadap materi yang telah dipelajari.

\section{Respon siswa}

Berdasarkan hasil penilaian respon siswa terhadap pembelajaran dengan menggunakan model pembelajaran Cooperative Script berbantuan media Adobe Flash pada materi hidrokarbon, sebagian besar siswa memberikan respon positif. Respon positif yang diberikan siswa ditunjukan dengan banyaknya siswa yang memberikan respon setuju dan sangat setuju dibandingkan dengan respon raguragu, tidak setuju dan sangat tidak setuju. Dilihat dari skor yang diperoleh siswa untuk respon terhadap pembelajaran menggunakan model Cooperative Script berbantuan media Adobe Flash ada sebanyak 13 orang siswa atau sebesar $33,33 \%$ termasuk kriteria sangat baik, 26 orang siswa atau sebesar $66,67 \%$ termasuk kriteria baik.

Respon positif siswa terlihat bahwa pembelajaran dengan menggunakan menggunakan model Cooperative Script berbantuan media Adobe Flash membuat siswa menjadi lebih tertarik untuk mengikuti pembelajaran dan memudahkan siswa memahami materi hidrokarbon.

Temuan yang didapat dari penelitian ini yang pertama yaitu siswa dapat melakukan kegiatan sesuai langkahlangkah pembelajaran Cooperative Script berbantuan media Adobe Flash yang membuat siswa lebih mudah dalam memahami konsep-konsep materi pelajaran. Adapun temuan yang kedua adalah adanya peningkatan aktivitas siswa dalam belajar karena pembelajaran yang diterapkan membuat siswa lebih aktif dalam membaca dan meringkas materi serta berdiskusi.

Adapun temuan yang ketiga adalah dalam kegiatan pembelajaran peran guru sangat penting terutama dalam memberi motivasi siswa dalam belajar. Peran guru pembelajaran dengan model Cooperative Script berbantuan media Adobe Flash adalah sebagai mediator dan fasilitator, dimana guru memilih dan menggunakan serta mengusahakan media dengan baik. Temuan keempat adalah media Adobe Flash yang digunakan ini membuat siswa menjadi lebih tertarik pada pelajaran dan termotivasi dalam belajar. Dengan motivasi yang tinggi maka siswa akan giat dalam belajar sehingga prestasi yang akan dicapai siswa akan mengalami peningkatan. Media Adobe Flash yang digunakan membuat siswa menemukan pengetahuannya sendiri, dimana media Adobe Flash ini dilengkapi dengan contoh-contoh soal, dan terdapat video yang dapat membuat siswa tertarik dalam belajar. Akibatnya siswa lebih aktif dalam aktivitasnya.

\section{PENUTUP}

1. Aktivitas siswa dalam pembelajaran menggunakan model pembelajaran Cooperative Script berbantuan media Adobe Flash mengalami peningkatan dengan kategori sangat aktif.

2. Penerapan model pembelajaran Cooperative Script berbantuan media Adobe Flash dapat meningkatkan motivasi siswa kelas XI MIA - 3 MAN 3 Banjarmasin Tahun Pelajaran 2016/2017 dengan kategori baik.

3. Penerapan model pembelajaran Cooperative Script berbantuan media Adobe Flash dapat meningkatkan hasil belajar kognitif siswa kelas XI MIA-3 MAN 3 Banjarmasin Tahun Pelajaran 2016/2017 dengan kategori sangat baik. Ketuntasan klasikal hasil belajar siswa 
meningkat dari $71,79 \%$ pada siklus I menjadi $82,05 \%$ pada siklus II.

4. Penerapan model pembelajaran Cooperative Script berbantuan media Adobe Flash dapat meningkatkan hasil afektif siswa kelas XI MIA -3 MAN 3 Banjarmasin Tahun Pelajaran 2016/2017 dengan kategori baik.

5. Siswa memberikan respon positif terhadap pembelajaran yang diterapkan oleh guru dengan menggunakan model pembelajaran Cooperative Script berbantuan media Adobe Flash pada materi hidrokarbon.

\section{DAFTAR PUSTAKA}

Abidin, Z. 2006. Motivasi Dalam Strategi Pembelajaran dengan Pendekatan ARCS. Fakultas Agama Islam Universitas Muhammadiyah, Surakarta. Dipublikasikan. Diakses melalui

http://publikasiilmiah.ums.ac.id/bitst ream/handle/123456789/890/4.\%20

Zaenal\%20Abidin.pdf?sequence $=1$ pada tanggal 10 Januari 2015.

Andreastomo, A. 2013. Meningkatkan Hasil Belajar dan Keterampilan Sosial Siswa Kelas XI IPA SMA Muhammadiyah 1 Banjarmasin Tahun Pelajaran 2012/2013 Pada Materi Sistem Koloid Melalui Model Pembelajaran Cooperative Script. Skripsi Sarjana. Universitas Lambung Mangkurat, Banjarmasin. Tidak dipublikasikan.

Dimyati \& Mudjiono. 2009. Belajar dan Pembelajaran. Rineka Cipta, Jakarta.

Djamarah, S. \& Zain, A. 2010. Strategi Belajar Mengajar. Rineka Cipta, Jakarta.

Huda, M. 2013. Model-Model Pengajaran dan Pembelajaran. Pustaka Pelajar, Malang.

Majid, A. 2013. Strategi Pembelajaran. PT Remaja Rosdakarya, Bandung.

Rahmadi. 2013. Modul Pembuatan Media Pembelajaran Menggunakan Macromedia Flash. Diakses melalui http://teknikmultimedia.file.wordpre ss.com/modul-pembuatan-mediapembelajaran . pada tanggal 14 Januari 2015.

Soelistiyanto, E. 2014. Penerapan Pembelajaran Model Cooperative Script untuk Meningkatkan Hasil Belajar pada Pokok Bahasan Evolusi Kelas XII IPA 3 SMA Negeri 2 Jember. Laporan Penelitian. Jurnal Universitas Jember. 3: 37-46.

Tiara, I., Sanjaya dan Rodi Edi. 2014. Pengaruh Penerapan Model Cooperative Script terhadap Hasil Belajar Kimia Siswa Kelas X SMA Negeri 3 Tanjung Raja. Laporan Penelitian. Jurnal Penelitian Pendidikan Kimia Universitas Sriwijaya, Palembang. 1:156-163. 
Jurnal PTK dan Pendidikan

Vol. 3 No. 2. Juli - Desember 2017 (1-9) 